\title{
Interview with Rosalind I. J. Hackett on Religion and Digital Media Trends in Africa
}

\author{
M Rosalind I. J. Hackett ${ }^{1}$, Frédérick Madore ${ }^{2}$, \\ Pamela Millet-Mouity ${ }^{3}$ \\ On October $21^{5 t}, 2017$, the editors of this special issue conducted an interview with \\ Rosalind I.J. Hackett, one of the pioneering scholars in the field of media and religion in \\ Africa. The interview took place via Skype and consisted of five questions on the study of \\ religion and digital media in the African context.
}

As one of the pioneering scholars in the field of media and religion in Africa (Hackett, 1998, 2005), do you think that the diverse religious transformations being generated by the explosion of new digital media technologies are so different from the impact of more traditional - or old - media?

JH: First of all, it is important to emphasize that because of Africa's great diversity, size, and complexity, we have to be cautious in making generalizations. We can point to trends, but in terms of general and comparative analysis, we simply do not have enough data or specific studies. The examples I will give to illustrate or support my responses will come from the areas that I worked on or that I am most familiar with, that is to say new religious movements, particularly Pentecostal-charismatic movements, and also traditional and indigenous religions. I cannot speak so much to the relationship between Islam and media in Africa.

As to your question about the impact of digital media, I would say no, and yes. No, in that I think what the older media did to connect people, to disseminate information, to help build and service religious communities is also being performed by the newer social media outlets, but with increased options for networking, learning, and ritual activities. It is my impression that digital media will supplement and complement, rather than supplant, the older forms of face-to-face religious communities, especially for those who have the technology - whether producers or consumers. Rather than leading to greater religious fragmentation, these new media enable people

\footnotetext{
${ }^{1}$ Department of Religious Studies, University of Tennessee (United States).

${ }^{2}$ Centre interdisciplinaire de recherche sur l'Afrique et le Moyen-Orient (CIRAM) Université Laval (Canada)

${ }^{3}$ Centre d'études en sciences sociales du religieux (CéSor) École des hautes études en sciences sociales (France)
} 
to engage in religious multitasking, such as performing daily devotions while on the move, at home or at work, or catching up on sermons and talks they could not attend. Do I think that these new media are going to radically change Africa's religious landscape? No. Will we see the birth of online religions? No, not at this stage, because of ongoing issues of accessibility and varying costs of mobile telephony for many African consumers.

However, one can note the growing use of new digital media - notably Facebook, Twitter, Instagram and YouTube - by some of the larger and more successful Pentecostal-charismatic organizations as they seek to proselytize, reach out to, and manage, their members, branches, and associations. New opportunities exist for researchers also, for the marketing impulse of these new media means that numbers of viewers and followers are often listed. An example comes from the Redeemed Christian Church of God (RCCG) in Nigeria which is one of the largest, if not the largest, Pentecostal-charismatic churches in Africa. Several hundred thousand people follow the founder, Enoch Adeboye, on Facebook ${ }^{4}$. Yet, RCCG is probably better known for the millions of people that attend their monthly Holy Ghost services and Annual Convention at the Redemption Camp on the Lagos-Ibadan Expressway. Thus we might say that digital media are still catching up on the appeal of the live worship services.

One area where the transformative capacity of new media might be more evident is in the area of proselytism and conversion. Church members are being commissioned to use the new media to convert, to bring visitors to services or to share tweets and YouTube videos. A case in point would be RCCG's “Let's Go Fishing” campaign that takes place at Christmas and Easter. Over time, this technologically enhanced agency may serve to benefit the larger, well-run churches and create a new super-league of African mega-churches, whose social and political power - and perhaps perceived religious power - derives from their mastery of the rapidly growing digital media sector.

Another possible consequence of increased digital mediation could be heightened forms of religious consumerism. In the not too distant past, religious seekers would check out, sometimes in Nicodemus fashion, other church options by attending their services. Nowadays, through the "shopping mall" of social media, those who have the means and the inclination can shop around and supplement their devotional lives by "following" other church leaders or institutions. For example, nearly 400,000 people "follow" on Facebook, Dr. Mensa Otabil, the charismatic and media-savvy founder and senior pastor of the International Central Gospel Church in Accra, Ghana. Not only do we need an expanded notion of a "follower," "devotee" or "member" in this digital age, but we would benefit from more information on how Africans use social

${ }^{4}$ Accessed December, 10, 2017, URL : www.facebook.com/rccg.org. 
media as part of their hourly/daily/weekly/occasional religious practice, either alone, in the company of others, or in their virtual religious communities. Such data might challenge our understanding of concepts of "allegiance" and "identity," as well as the actual or perceived boundaries between religious organizations themselves.

If social media offer new ways of connecting and belonging, then we should pay particular attention to the relationship between centers and peripheries, i.e. between church headquarters and their diasporic communities. If communities in London or Chicago are more engaged on social media, as would seem to be the case for the Redeemed Christian Church of God. One of the RCCG Twitter feeds has the national flags of the users and it shows greater use in the diaspora than from the country of origin (Nigeria). Might that translate into a shift in power relations or challenges to institutional management in ever-expanding Pentecostal-charismatic religious empires? Or does it represent new ways of tapping into the power source at the center, the anointed "man of God" or less commonly, "woman of God"?

Just as it is interesting to track sermon content of prominent Pentecostalcharismatic leaders in varying locations and for different constituencies, we might also consider their choice of digital media -or combination thereof - for delivering their messages. That could also extend to neo-traditionalist religious leaders and advocates, such as the Ghanaian priest or "spiritualist", Nana Kwaku Bonsam, who lived for a time in New York ${ }^{5}$. He has a strong presence on YouTube, from which he posts to Facebook along with various Twitter hashtags - his own and those of his Pentecostal-charismatic "enemies". The videos often show him in traditional settings, sometimes with his laptop or phone at hand. His frequent public pronouncements on political and social issues - even the national soccer team -, as well as his "revelations" about his clientele assure him coverage on breaking news online platforms, such as BuzzFeed.

As separation between religious uses of the Internet and more traditional "offline" religious practice is becoming increasingly blurred and blended, Heidi Campbell (2012) proposes the term "digital religion" for articulating the evolution of online religious practice which is linked to online and offline contexts simultaneously. According to her, this concept "does not simply refer to religion as it is performed and articulated online, but points to how digital media and spaces are shaping and being shaped by ['offline'] religious

\footnotetext{
${ }^{5}$ He was featured in The New York Times: Jed Lipinski, "A Visit From the Devil. Feared Traditional Priest From Ghana Spends a Year in the Bronx", July 19, 2013, accessed December, 10, 2017, URL : www.nytimes.com/2013/07/21/nyregion/feared-traditionalpriest-from-ghana-spends-a-year-in-the-bronx.html.

${ }^{6}$ E.g. My Message To False Prophecies By False Prophet About 2016 Elections And The Peace Of The Nation TB Joshua And Owusu Bempah And Other Prophet. We Need Peace In The Country.\#nana kwaku bonsam\#TB Joshua\#Rev. Owusu Bempah\#Npp\#ndc\#TB Joshua Ministries\#\#FACT\#nana kwaku Nana Kwakoe Bonsam\#UTVNEWS\# (November 18, 2016).
} 
practice." For the author, the "online" and "offline" religious spheres have become connected and integrated. How are these two realities interacting or are they still separate in the African context?

JH: I would say there is more religion online that there is online religion in Africa ${ }^{7}$, so it would be premature to speak of an integration between the "online" and "offline" spheres. I have come across one reference to an online church and that was an RCCG subcommunity. The bulk of what we find online complements the offline religion, namely attending worship services. This is hardly surprising if we think about the significance of sociality in Africa and the church as a safe, social space. This is particularly the case for women. Given the general trend toward media convergence, certainly facilitated by digital media, we can predict that there will be greater interdependence between online and offline religion. This is not a new phenomenon. Muhammed Haron was writing about mediation and remediation - broadcast/livestreaming/call-in/archived recordings - on Muslim radio stations in South Africa nearly two decades ago $(2002,2014)$.

In an age of neoliberalism, media developments are being shaped by business models. A case in point is the new media company OMG Digital that is targeting Africa's millennial population "through shareable and hyper-local pop-culture content" ${ }^{8}$. It has been dubbed the "Buzzfeed of Africa" with its OMGVoice brand. It has monthly aggregated content views of over 90 million, a monthly social reach of 80 million, with 4.5 million readers to the website each month since its launch in February 2016. Currently operating in Ghana, Nigeria and Kenya, its team "creates and curates listicles, pictorials, videos and memes that are tailored to specific African countries and cultures". The start-up company notes that millennials, who make up more than a third of the continent's population (approx. 250 million+), are "the most connected generation with a strong affinity to mobile technology and social media usage." Not surprisingly, given the rapid growth of mobile telephony in some African countries, they claim that $90 \%$ of OMG's subscribers visit from a mobile - predominantly Android - device. Their goal is "to dominate the social feeds of millennials across the continent" and to "grow their advertising and marketing operations and investing in producing more video content." It will be interesting to follow their coverage of religion, given that Internet-savvy, African youth are less likely to be found in the "nones" category, as would be their counterparts in the global North.

\footnotetext{
${ }^{7}$ Some scholars such as Helland (2000) and Dawson (2000) have distinguished religious organizations or groups, and practices which exist only in cyberspace - "online religion" from information and rituals that are largely based on offline sources - "religion online."

${ }^{8}$ Accessed December, 10, 2017, URL : https://africabusinesscommunities.com/news/ghanabuzzfeed-for-africa-omg-digital-secures-\$1.1-million-seed-funding.
} 
Religion, more specifically, Christianity, is up front and central with the new platform known as Asoriba that began in Ghana in 2015'. It was featured on CNN in November the following year as "[t]he app that's changing religion in West Africa ${ }^{10}$." It won Ghana's best Startup Award in 2015 and Africa's Best Startup Award in 2016. Their website asks: "How can we help your church? We are your ministry's software partner, enabling you to manage your church administration and membership seamlessly [...] Discover the great benefits of our cloud based management software, its accompanying mobile app \& online giving tool." We learn that they are experts in "Member Management". They purport to "Capture deep member data and receive notifications about special dates like birthdays and wedding anniversaries. Record family relationships, work, education and any other information you find relevant. View tithes, contributions, prayer request history, groups joined and attendance frequency of a member. Seamlessly transfer a member to another branch of your church and communicate via our asoriba mobile app." All of this sounds like an answer to the prayers of mega-church administrators - and researchers.

In the CNN article, the reporter poses the salient question: "Is digital spiritual?" Their answer: "Part of Asoriba's appeal is its ability to connect churchgoers to the church without them physically attending a service." In case of fears that this app might displace face-to-face worship, the next sentence is reassuring: "For those traveling or too busy to attend, the Sunday service can be downloaded, or even livestreamed, through Asoriba". Next key question: "Is anything lost with going from a physical to digital connection?" Nana Prempeh, the co-founder of Asoriba, answers: "You can never replace your real life connections. However, you can enhance the physical connections and go beyond." At least from an institutional perspective, this underscores what I have argued about the synergy between online and offline religion.

In an interview in a special issue of Social Compass (2014), you have identified research on religiously related Internet sites as well as social media - Facebook, YouTube, and Twitter - as topics that urgently need to be addressed in the study of African religions and media. However, even if Internet accessibility and the use of smartphones in Africa are rapidly increasing since then, scholarship on religious media remains largely focused on mass media - TV, radio, newspapers/print media - and small media - video films, audio cassettes, CDs, DVDs - while digital media seems to remain largely understudied. For example, in the book New Media and Religious Transformations in Africa that you have coedited with Benjamin Soares (2014), only a few contributions were studying more directly digital media. What are your thoughts?

\footnotetext{
${ }^{9}$ Accessed December, 10, 2017, URL : www.asoriba.com.

${ }^{10}$ Sophie Morlin-Yron, CNN, November 11, 2016, accessed December, 10, 2017, URL : www.cnn.com/2016/05/17/africa/asoriba-church-app-ghana/index.html.
} 
JH: As you rightly suggest, digital media remain a neglected area of research in studies of religion and media in Africa. Several reasons could be adduced: such research is technologically intimidating, time-consuming, and challenging to access and keep up with. There may be concerns that this is not a "serious" topic for academic inquiry. Scholarship on this topic is mainly predicated on the Western world, or, if it does treat Africa, it does not factor in religion, as in the Journal of African Media Studies which concentrates more on the impact of new media on democracy, activism, and African journalism. We need to rethink our research methods to produce ethnographically rich, and methodologically and theoretically productive research, that goes beyond mere data collection to generate statistics and focuses on user practices and attitudes.

Digital media could pose a serious challenge for African states as they are much more difficult to regulate than "traditional" media. Based on your observations, how have religious movements seized the opportunities offered by the Internet and social media, such as the greater freedom of speech, to promote more actively their religious, social and political agenda in the public sphere?

JH: Religious leaders are much more aware now about how they are being digitally recorded, captured, and remediated. Some of that was happening with the growth of mass, particularly broadcast, media. While there may indeed be more opportunities across the board for religious self-expression through social media rather than the "old" media, ironically the "new" media may introduce constraints, if not standardization, in terms of format, temporality, and image size, and number of characters. There have been instances of governments shutting down or introducing legislation to monitor social media communications during political and religious unrest, as in the case of Tanzania ${ }^{11}$. A more cooperative response comes from Sierra Leone after a popular Nigerian Christian preacher Victor Ajisafe delivered a sermon that demonized Islam ${ }^{12}$. Someone recorded his sermon and it went viral on social media within three days, eliciting a speedy intervention from the government and religious leaders and leading to the arrest of Ajisafe. In some of my earlier work, I argued for more research on the intolerance and the conflict that religious media can provoke or intensify in South Africa and Nigeria (Hackett, 2006, 2012). Given that Facebook is so popular in Africa, and that it blurs the edges between what is public and private, I expect it

\footnotetext{
${ }^{11}$ Accessed December, 10, 2017, URL : http://allafrica.com/stories/201709250216.html. ${ }^{12}$ Cooper Inveen, "Sierra Leone arrests pastor who blamed Islam for "every terrorist act in history," The Guardian, 27 September 2017, accessed December, 10, 2017, URL: www.theguardian.com/global-development/2017/sep/27/sierra-leone-arrests-pastor-whoblamed-islam-for-every-terrorist-act-in-history-victor-ajisafe.
} 
to be more contentious in the future on religious matters given that it provides a lively, accessible forum for individual and group expression, debate, and critique.

What is your advice for young scholars wanting to conduct research in the field of digital media and religion in Africa? What are the main methodological difficulties? What are the important topics for future studies on this subject?

JH: As noted above and in the literature, there are particular challenges to conducting research on digital media ${ }^{13}$, especially when it comes to religious engagement and experience (Campbell and Vitullo, 2016). It would help to decide what to focus on in one's research: an organization, platform, leader or leaders, user group, user category or individual user. The timeframe is important, too: is this to be short-term research or a longitudinal study ${ }^{14}$ ? Needless to say, there are a range of deployable theoretical or thematic concepts for this area of research: agency, affordance, affect, experience, performance, authority, identity, authenticity, proselytization, community/communitas, discourse, and ritual practice. As noted by Campbell and Vitullo (2016), key questions that have emerged from the more recent research phase are to document and analyze the relationships between changing digital and religious cultures, and between online and offline religion. Furthermore, they claim, it is not just what religious Internet users do online that should interest us, but how they interpret and perceive these practices in relation to their broader religious and social identities $^{15}$.

Conducting research on the growing imbrications of religion and social media in the African context presents challenges in terms of data collection and related ethical and access issues, but should also prove rewarding in that such studies will be pioneering, timely, and of comparative interest. Researchers might be able to benefit from general awareness of rapid media growth, and associated market research, and work with religious leaders and communities to investigate questions of mutual interest. Africa-based research could yield rich data on religious or spiritual perceptions of social media as magic/occult/divinely empowered. Given Africa's highly competitive religious public spheres, and the fact that the conflictual relationships between Pentecostal-charismatic leaders are often conducted via modern media, would be grist for a researcher's mill.

\footnotetext{
${ }^{13}$ For a helpful overview of research on digital audiences in general, see De Ridder, VesnicAlujevic, and Romic (2016).

${ }^{14}$ Consider the value of Birgit Meyer's superb (two decade long) longitudinal study on the Ghanaian video film industry and religious world-making (2015).

${ }^{15} \mathrm{See}$, for example, the Journal of Media, Religion and Digital Culture.
} 


\section{Bibliographie}

CAmpbell H. A. (dir.) (2012), Digital Religion: Understanding Religious Practice in New Media Worlds, New York, Taylor \& Francis.

CAmpbell H. A., Vitullo A. (2016), « Assessing changes in the study of religious communities in digital religion studies », Church, Communication and Culture, vol. 1 , $\mathrm{n}^{\circ} 1$, p. 73-89.

DAWSON, L. L. (2000), « Researching Religion in Cyberspace: Issues and Strategies », in J. K. HADDEN, D. E. CowAN (dir.), Religion on the Internet: Research Prospects and Promises, New York, JAI Press, p. 25-54.

DE RidDER S., VeSNiC-AlujeVIC L., Romic B. (2016), « Challenges when researching digital audiences: Mapping audience research of software designs, interfaces and platforms », Participations: Journal of Audience er Reception Studies, vol. 13, n 1, p. 374391.

HacketT R. I. J. (1998), « Charismatic/Pentecostal Appropriation of Media Technologies in Nigeria and Ghana », Journal of Religion in Africa, vol. 28, n 3, p. 258-277.

HACKETt R. I. J. (2005), « Religion et Internet », Diogène, vol. 211, nº 3, p. 86-99.

HaCKetT R. I. J. (2006), « Mediated Religion in South Africa: Balancing Airtime and Rights Claims », in B. MEYer, A. Moors (dir.), Religion, Media and the Public Sphere, Indianapolis, Indiana University Press, p. 166-186.

HACKeTt R. I. J. (2012), « “Devil Bustin’ Satellites”: How Media Liberalization in Africa Generates Religious Intolerance and Conflict », in J. H. SMITH, R. I. J. HACKETT (dir.), Displacing the State: Religion and Conflict in Neoliberal Africa, Notre Dame, University of Notre Dame Press, p. 163-208.

Hackett R. I. J., Melice A., VAN Wolputte S., PyPe K. (2014), « Interview: Rosalind Hackett Reflects on Religious Media in Africa », Social Compass, vol. 61, n 1, p. 6772.

HaCketT R. I. J., SoARes B. F. (dir.) (2014), New Media and Religious Transformations in Africa, Bloomington, Indiana University Press.

Haron M. (2002), « The South African Muslims Making (Air)Waves during the Period of Transformation ", Journal for the Study of Religion, vol. 15, n² 2, p. 111-144.

HARon M. (2014), « Muslim Community Radio Stations: Constructing and Shaping Identities in a Democratic South Africa », in R. I. J. HACKETT, B. F. SOARES (dir.), New Media and Religious Transformations in Africa, Bloomington, Indiana University Press, p. 82-96. 
Helland C. (2000), « Online-Religion/Religion-Online and Virtual Communities », in J. K. HADDEN, D. E. CowAN (dir.), Religion on the Internet: Research Prospects and Promises, New York, JAI Press, p. 205-223.

Meyer B. (2015), Sensational Movies: Video, Vision, and Christianity in Ghana, Oakland, University of California Press. 
